DOE/EIA/TR-0253

\title{
The Substitution of Coal for Oil and Natural Gas in the Industrial Sector
}

November 1980

\section{U.S. Department of Energy}

Energy Information Administration

Assistant Administrator for Applied Analysis

Washington, D.C. 20461

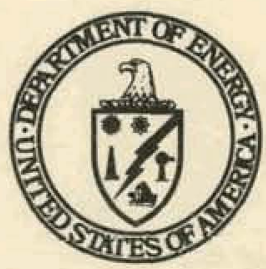




\section{DISCLAIMER}

This report was prepared as an account of work sponsored by an agency of the United States Government. Neither the United States Government nor any agency Thereof, nor any of their employees, makes any warranty, express or implied, or assumes any legal liability or responsibility for the accuracy, completeness, or usefulness of any information, apparatus, product, or process disclosed, or represents that its use would not infringe privately owned rights. Reference herein to any specific commercial product, process, or service by trade name, trademark, manufacturer, or otherwise does not necessarily constitute or imply its endorsement, recommendation, or favoring by the United States Government or any agency thereof. The views and opinions of authors expressed herein do not necessarily state or reflect those of the United States Government or any agency thereof. 


\section{DISCLAIMER}

Portions of this document may be illegible in electronic image products. Images are produced from the best available original document. 


\section{The Substitution of Coal for Oil and Natural Gas in the Industrial Sector}

November 1980

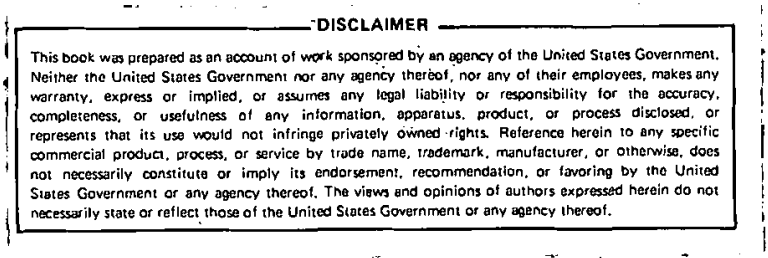

Prepared by:

Barry N. Cohen

Office of Energy Use Analysis

\section{U.S. Department of Energy}

Energy Information Administration

Assistant Administrator for Applied Analysis

Washington, D.C. 20461

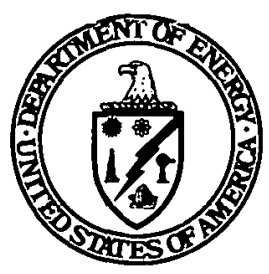


This publication is available from the superintendent of Documents, U.S. Government Printing office. An order form is enclosed for your convenience. Send order form and payment to:

$$
\begin{aligned}
& \text { Superintendent of Documents } \\
& \text { U.S. Government Printing Office } \\
& \text { Washington, D.C. } 20402 \\
& \text { Order Desk (202) 783-3238 } \\
& \text { Stock Number: } 061-003-00157-2 \\
& \text { Price: } \$ 3.25
\end{aligned}
$$

For questions on energy statistics or information on availability of other EIA publications, contact:

U.S. Department of Energy

Energy Information Administration

National Energy Information Center, FI $-6 I$

Forrestal Building

Mail stop 1F048

Washington, D.C. 20585

(202) 252-8800

Released for printing: December 12, 1980 
CONTENTS

Page

Preface................................

Executive Summary............................ xi

Introduction. $\ldots \ldots \ldots \ldots \ldots \ldots \ldots \ldots \ldots \ldots \ldots \ldots \ldots \ldots \ldots$

1. Technical Feasibility.................... 2

Conventional Technology - Direct Coal Use......... 3

Boiler Fuel Use....................... 4

Atmospheric Fluidized Bed Combustion............ 6

Coa1-Derived Synthetic Fuels................ 8

Low- and Medium-Btu Gases.................... 10

Solid Solvent Refined Coal (SRC-1).............11

Liquid Solvent Ref1ned Coal (SRC-2)..............12

Coal/0i1 Mixture..........................

2. Coal Use in Energy Intensive Industries...............

Food Industry $\ldots \ldots \ldots \ldots \ldots \ldots \ldots \ldots \ldots \ldots \ldots \ldots \ldots \ldots$

Textile Industry........................

Stone, Clay, and Glass Industry................

Petroleum and Chemicals.......................

Steel and Aluminum Industries................21

3. Factors Affecting Industrial Coal Use..............23

Industrial Energy Prices......................

Environmental Regulations Affecting Coal Use........27

National Ambient Air Quality Standards (NAAQS)........29

State Implementation Plans (SIPs)............... 
CONTENTS (Continued)

Page

Prevention of Significant Deterioration (PSD) ........... 31

Energy Legislation Promoting Industrial Coal Use.......... 33

Natural Gas Policy Act (NGPA) ................... 33

Powerplant and Industrial Fuel Use Act (PIFUA).......... 34

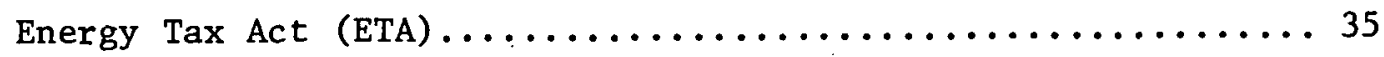

4. Forecast of Industrial Coal Use.................... 36

Table

1. Industrial Energy Prices -- H1story and 1979 Annual Report to Congress, Medium Casc Projections, 1965-1995 (1979 dollars

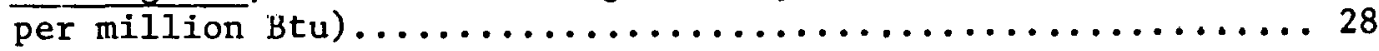

2. Industrial Energy Consumption: History and Projections, 1965-

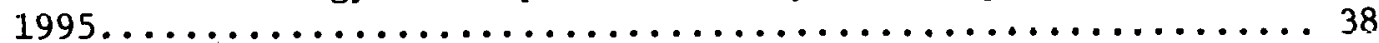




\section{PREFACE}

This report was prepared by Barry N. Cohen of the Office of Energy Use Analysis, Energy Information Administration, U.S. Department of Energy. It is part of the Coal Competition and Market Performance Study mandated by Section 742 of the Powerplant and Industrial Fuel Use Act (PIFUA) of 1978. The report considers the degree to which coal can be used as a substitute fuel for oil and natural gas. in the industrial sector in the near anci distant future. This report summarizes, synthesizes and expands upon three reports already submitted to Congress:

- Technical and Economic Feasibility of Alternative Fuel Use in Process Heaters and Small Boilers 1 .

- Energy Information Administration Annual Report to Congress, $1979^{2}$

- Energy Programs/Energy Markets ${ }^{3}$

The author wishes to extend his appreciation to both Takashi Takayama and Terry Morlan for their helpful comments.

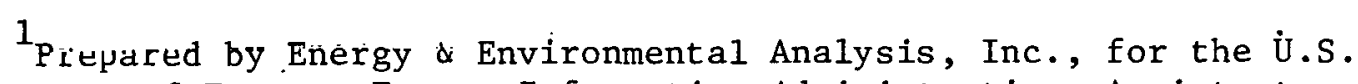
Department of Energy, Energy Information Administration, Assistant Administrator for Applied Analysis, DOE/EIA-10547-01, February. 1980. This report was prepared in response to Section 747 of the Powerplant and Industrial Fuel Use Act of 1978

${ }^{2}$ U.S. Department of Energy, Energy Information Administration, 1979 Annual Report to Congress, Volume III, DOE/EIA-0173(79)/3.

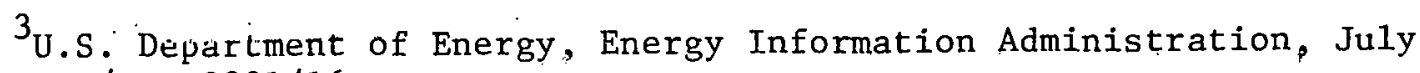
1980, DOE/EIA-0201/16. 


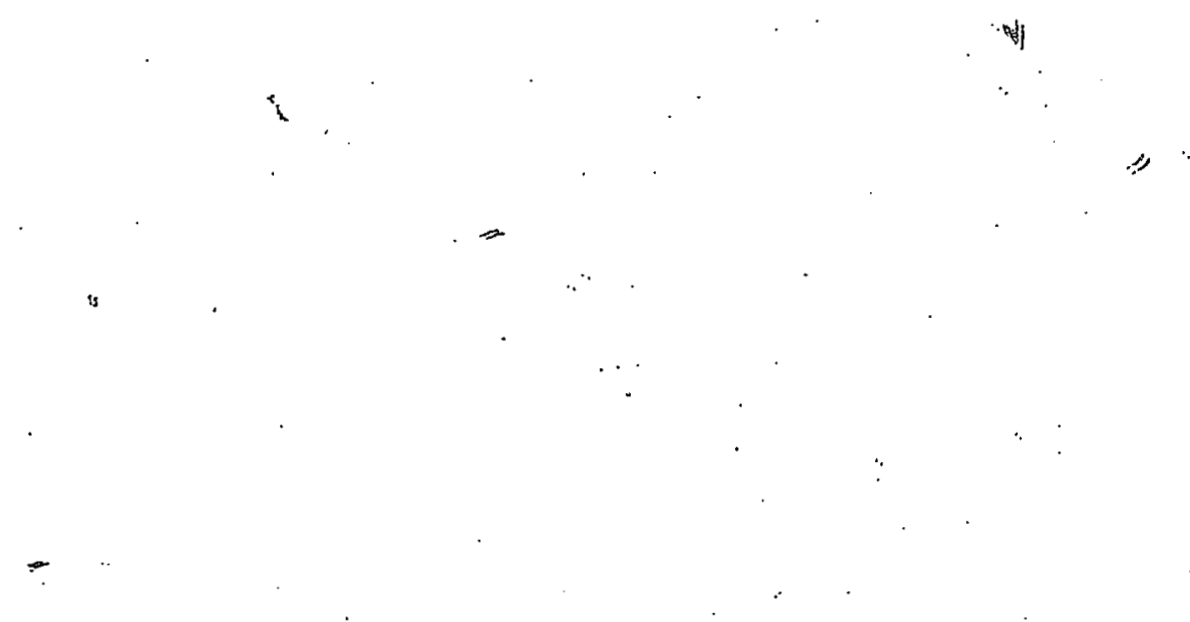

THIS PAGE

WAS INTENTIONALLY

LEFT BLANK 


\section{EXECUTIVE SUMMARY}

Increased reliance on coal is a central tenet of the Nation's strategy for meeting its energy needs. Coal is our most plentiful domestic fuel resource and U.S. coal reserves are hundreds of times greater than present annual production rates. ${ }^{1}$ Nevertheless, the use of coal has declined in recent decades in all sectors except the electric utility sector.

Coal used to generate electricity in central power stations now accounts for nearly four-fifths (529 out of a total of 681 million tons) of all domestic coal consumption. The remainder is about equally distributed between coke plants and other industrial consumers. ${ }^{2}$ This picture is in stark contrast to coal consumption patterns existing after World War II. At that time the industrial sector consumed nearly half of all domestic coal consumption and the utility sector accounted for less than one-fifth of coal use. Current industrial (nonmetallurgical) coal demand is litcle more than half of its 1950 level of 121 million tons.

Recent projections of industrial coal demand depart dramatically from the stagnant historical picture presented above. In a recent Department of

${ }^{1}$ In 1979 nearly 750 million tons of coal were produced in the United States compared to a demonstrated coal reserve resource base of about 430 billion tons.

\section{Annual Report to Congress, 1979 (ARC 79), Energy Information} Administration, U.S. 'Department of Energy, Volume 2, p.113. 
Energy publication, total industrial coal use is projected to reach 325 million tons by 1990 , more than twice the current consumption level. 3

This report evaluates the substitutability of coal for oil and natural gas use. It emphasizes the technical characteristics of fuels and energy using equipment that affect fuel choice decisions.

\section{Midtcrm Forccasta}

Within the next 1 b years, this report concludes, direct coal use in conventional boilers will domfnate Industrlal coal demand. Coal use in cement and lime kilns (already proven and economic technologies) will be the only major, non-boiler industrial fuel uses of coal.

Coal demand forecasts presented in this report are based solely on the projected market penetration of conventional coal-based technologies. Such coal use is projected to increase substantially over current levels. By 1990, non-feedstock use of coal is projected to reach 230 million tons, about $3 \frac{1}{2}$ times the current consumption level.

Two factors are primarily responsible for the rapid increase in coal use:

(1) Coal's current and projected relative fuel price advantage, and

(2) Provisions of the National Energy Act of 1978.

Delivered residual oil prices are projected to increase at an average annual rate of 8 percent between 1978 and 1990 , compared to a rate of only

3 These projections include both metallurgical coal use and other industrial coal use, Annual Report to Congress, 1979, Volume III. 
4.4 percent for coal. Natural gas (the least expensive fuel in the preoil embargo era) is projected to face the highest annual rate of increase in price, nearly 10 percent.

In addition to coal's increasing relative fuel price advantage, several elements of the National Energy Act of 1978 are designed to improve coal's competitiveness.

In particular:

- The Natural Gas Policy Act of 1978 increases the price of natural gas to most industrial customers

- The Powerplant and Industrial Fuel Use Act of 1978 prohibits the use of oil and natural gas in new boilers with a firing rate of 100 million Btu per hour or greater

- The Energy Tax Act of 1978 provides for special investment tax credits and accelerated depreciation methods for investments in coal and other alternative energy sources

\section{Long Term Outlook}

By the year 2000, new coal-based synthetic fuels may play a major role in the industrial sector. This report describes a sample of such technologies including low-and medium-Btu gasification and solid and liquid solvent refined coal.

In the long term, the commercialization of such coal-based synthetic fuels may greatly extend the substitutability of coal for natural gas and oil. Direct coal use in many combustors is currently limited by problems associated with firing a solid fuel and contaminants contained in coal. 
These problems can be minimized by processing the coal into a liquid or gaseous form that is more compatible with the current fuels used in such combustors. The costs, however, of such processing vary considerably from one pilot project to another, making it difficult to develop quantitative estimates of coal-based fuels' market penetration.

The Department of Enorgy and the nrivate sertor are continuing research, development, and commercialization programs to reduce the uncertainties associated with synthetic fuel production from coal. Construction of the $\$ 1.4$ billion Great Plains Coal Gasification Plant in North Dakota was scheduled to begin in August of 1980. This plant will produce pipeline quality (high-Btu) gas from coal. It is financed by a consortium of energy companies with loan guarantees from the Department of Energy. 
INTRODUCTION

This report considers the increasingly important role that coal is projected to play in meeting the future energy requirements of the industrial sector. Projections presented in the Energy Information Administration's (EIA) Annual' Report to Congress, '1979 (ARC 79), and reproduced in this report, estimate that industrial coal consumption will more than double over the 1979-1990 time period. Such a rapid increase in industrial coal use may have important implications for coal market performance and the level of competition in the coal industry.

$\therefore$

Chapter 1 of this report discusses the feasibility of using coal in specific industrial energy use applications. Technical constraints to conventional coal use are examined, as are some of the new coal-based technologies which may overcome many of these constraints. Chapter 2 focuses this discussion toward the major energy consuming industries. In Chapter 3, the major factors affecting the projected increase in industrial coal demand within the 1990 time frame are examined. These include relative energy prices, environmental constraints, and energy legislation. In Chapter 4 , ARC 79 industrial fuel use projections are discussed with emphasis on the projected changing industrial fuel mix through 1990. These projections consider only conventional technologies. 
In the next decade, the direct use of coal in conventional combustors will dominate industrial coal use. Nevertheless, coal derived fuels including low- and medium-Btu gas and solid (SRC-1) and liquid (SRC-2) solvent refined coal continue to receive a great deal of support and attention. These synthetic fuels may significantly increase the feasible range of industrial coal applications. This seclioll discusses the technical feasibility of using coal and coal-derived fuels in boilers and process heaters. 1 It relies heavily on technology descriptions developed for the report Technical and Economic Feasibility of Alternative Fuel Use in Process Heaters and Small Boilers, prepared in response to Section 747 of the Powerplant and Industrial Fuel Use Act of 1978.

\section{Technica1. Factors that Affert Fue1 Use}

Technical feasibility is defined, in this report, as the ability of a technology to produce, safely and reliably, the same quality product as a conventional oil or natural gas unit. Site-specific requirements, including space limitations and local enviromental regulations are not conoidorod in this defintrion. Nur de tuunuic or lcad time factore. This definition, while restrictive, is useful for identifying those technical characteristics of fuels that will limit their use regardless of fuel prices and government pulicies.

${ }^{1}$ Process heaters include a diverse collection of combustors including furnaces, kilns, and tubestill heaters, for example. 
It is important to distinguish between retrofit and new combustor fuel choices. New units have considerable flexibility in designing a process to burn various fuels. Retrofit fuel decisions, however, are much more limited by the existing design of the combustor and plant configuration.

The factors considered in evaluating technical feasibility in this report include:

- Heat flux, the amount of heat transferred per area per unit of time (indicates how "concentrated" the heat is)

- Heat distribution, the ability to provide controlled temperatures and heat flux over time and the volume of the furnace chamber

- Fuel contaminants, impurities present in fuel and released during combustion. These impurities (e.g. sulfur and ash) can degrade the work-piece and hasten the deterioration of the furnace

- Process temperature, the temperature required to meet the chemical or physical requirements of the process

Conventional Technology -- Direct Coal Use

The use of coal in the industrial sector is projected to more than double by 1990 from the 1978 consumption level of about 150 million tons per year. ${ }^{2}$ Much of this growth will occur in conventional industrial boilers. Coal use is not likely to expand significantly beyond its use in cement and lime. kilns in the process heater category until after 1990, if at all. Technical considerations usually preclude coal use in this end-use category.

2 This figure includes both feedstock and fuel use of coal. 
Conventional coal use, for example, "often cannot satisfy the heat" distribution requirements of many process heaters due to flame size and instability. In order for coal to produce a steady flame pattern it must be fired in burners larger than 50 million Btu per hour. In many applications (e.g. petroleum refining and chemical industry process heat applications), this minimum burner size requirement eliminatcs coal from ronsideration. In addition, unltke liquid or gaseous [uels, the heat released from an individual coal burner cannot be held constant. Coal, like solid fuels, is a heterogeneous mixture. The fuel delivery system cannot control the Btu delivered within the accuracy needed for some heaters because the pulverized particle size and the Btu cuntent vary. In some installations, such as brick kilns, only the average heat release is important. Other furnaces, however, such as an ethylene furnace cannot tolerate fluctuating heat release rates.

Another factor limiting conventional coal use in process heaters is the level of fuiel contaminants fuund in coal. These contaminants (primarily sulfur, vanadium, and ash) can impair product quality and accelerate the corrosion of the furnace and heat recovery systems.

\section{Boiler Fuel Use}

Boilers use fuel to produce steam from water for process uses, space heating, and electricity generation. Boilers consume more oil and gas than any single industrial consumption process. Although types of boilers (combustors size, capacity utilization, temperature and pressure capability) 
vary within the industrial sector, the cost and the technical capability to utilize fuels are generic for each boiler type.

Major industry groups can be categorized as predominantly boiler or process heat industries. The boiler industries include food, textiles, paper, and chemicals. In each of these industries two-thirds or more of the fuel use of oil and gas is consumed in boilers. ${ }^{3}$ The boiler industries can be classified further as industries using small boilers (e.g., food and textiles) or industries using large boilers (e.g., paper and chemical manufacturing).

In the food industry, steam is used primarily for washing and sterilizing containers, cooking, evaporating, space heating, and electricity generation. The textile industry relies heavily on purchased electricity to drive the machinery in the plants.

Steam is used for fabric preparation, dyeing, and finishing operations as well as space heating. Very little electricity is generated in textile mills.

The large boiler industries, paper and chemical manufacturing, use a significant portion of process steam to generate electricity. In chemical manufacturing, steam demand is used to strip away unreacted feed, as dilution steam, and to drive steam compressors. Process steam in the paper industry is used to generate electricity in the pulping and bleaching processes. Some systems also use steam in debarking.

${ }^{3}$ Industrial Fuel Choice Analysis Model, Model Documentation, (Energy Environmental Analysis, Inc., June 1980), pp. 3-14. 
The technical constraints on boiler fuel use are minimal. The major constraint is that the materials and design of the combustor be appropriate to withstand potential attack from the heat source. This is not a difficult constraint to overcome, and each of the coal-based fuels described below can be used in boilers. Boiler use of coal is projected to dominate industrial coal use through 1990.

\section{Atmospheric Fluidized Bed Combustion}

Atmospheric fluidized bed combustion (AFBC) of coal is an alternative technology for using coal directly. It consists of burning coal (or other fuels) in a bed of noncombustible material maintained in a fluid-1ike state by the flow of combustion air through the bed. The particle bed may consist of inert materials, such as sand, or a reactive material, such as limestone, used to capture $\mathrm{SO}_{2}$ (sulfur dioxide) as it is generated during the combustion process. AFBC can be used for various applications such as steam generation and heating proc'ess fluids.

AFBC originally was developed to reduce the boiler size required for coal combustion and, thereby, reduce cost, lessen fuel pre-preparation needs, and produce a system capable of burning a diversity of fuels. As the environmental hazards associated with burning coal received more attcntion, the intent has shifted toward involving AFBC as a potential alternative to flue gas desulfurization. (FGD) in coal-fired systems. In:addition to firing all grades of coal, some AFBC designs can fire wood, wood waste, fuel oils, and natural gas. A combination of fuels also may be fired simultaneously. 
AFBC systems for the production of steam; have the following advantages over conventional coal boilers:

- High heat transfer coefficients and volumetric heat release rates (about three or more times compared to conventional pulverized coal boilers) which can

- reduce boiler size by one-half or two-thirds of a conventional unit

- enable units generating up to 200/KPPH (thousand pounds of steam per hour) of steam to be shopmanufactured (conventional coal-firëd units above $50 \mathrm{KPPH}$ steam generally cannot be shop-manufactured)

- The use of limestone as bed material, which provides a means of $\mathrm{SO}_{2}$ removal (removal efficiencies of 90 percent or more can be achieved by using appropriate amounts of limestone)

- The high heat transfer coefficients in the hed al1 nw 1 ower operating temperatures $\left(1500-1750^{\circ} \mathrm{F}\right)$, which potentially. can decrease $\mathrm{NO}_{\mathbf{x}}$ (nitrous oxides) emissions

- The firing of variety of fuels, including ail grades of coal, wood and wood waste, fuel oils, and gas

Most of the AFBC systems being developed are coal-based and utilize water/ steam as the medium of heat transfer. "In these systems, the heat transfer surface is immersed in the fluidized bed, via vertical or horizontal tubes, and the heat is transferred to the water/steam flowing within the tube. The heat transfer surface serves the dual functions of extracting the heat of combustion from the bed and controlling the bed temperature to a desired level. Since the heat release rates in the bed are quite high, it is essential that the heat transfer medium extracts a sufficient quantity of heat to maintain the bed temperature within desired limits.

The maximum temperature to which fluids can be heated depends upon the bed temperature. A fairly narrow range of operating temperatures has been 
established for the fluidized bed boilers burning coal. A bed temperature of approximately $1500^{\circ} \mathrm{F}$ is considered optimum for $\mathrm{SO}_{2}$ removal. Temperatures above 1400 \% are desirable to achieve rapid combustion and $\mathrm{SO}_{2}$ removal; at temperatures above $1600^{\circ} \mathrm{F}$, however, sulfur removal activity of the limestone drops. At even higher temperatures, alkali metals volatilize and $\mathrm{NO}_{\mathrm{X}}$ generation Increases rapidly. Deposition of ash on the heat transfer surface also poses a potential problem.

Coal-Derived Synthetic Fuels

Factors already discussed (e.g. flame characteristics, heat distribution, and level of contaminants) severely limit the direct combustion of coal in process heaters. However, coal-derived synthetic fuels, discussed below, may greatly increase coal use in liese cumbustors in the futurc. Coal liquefaction and gasification have, and continue to be, extensively resparrhed and there appear to be nu serious technical constraints precluding further development. There is, however, no cxisting "synfuels" industry in the U.S. that can supply large quantities of coal-derived fuels. The development of such an industry within acceptable environmental and worker safety guidelines may take a considerable amount of time, even after coal-based synthetic fuels are commercially demonstrated to be economic alternatives to oil and gas.

Cost estimates for coal-derived fuels are difficult to predict because of the absence of commercial experience. Less than a decade ago it was . thought that coal liquefaction would be competitive if the price of crude oil doubled. Since then the price of crude has gone up more than fivefold 
and coal liquefaction may still not be price competitive. Since cost data for these technologies have not been firmly established they are not discussed in this report. 4

The designation "feasible" (no serious technical constraints) in this study does not mean that an energy source is economically attractive and/or will penetrate the market significantly within the next 10 years. The discussion here refers only to technical issues for the end user and does not consider developmental and market penetration lead-time or environmental and worker safety issues.

The coal-based synthetic fuels that are discussed in some detail below were chosen because they are representative of current research, demonstration, and commercialization programs. They do not exhaust the list of coalbased technologies now being investigated but they are thought to be representative of the technical characteristics of these new coal-based fuels. It should be stressed that the market penetration of these synthetic fuels has not been considered in the projection of industrial coal demand presented in Chapter 3.

The remainder of this chapter provides background and technical information concerning synthetic coal-based fuels. It is included in the report since these (and other) technologies may greatly extend the potential role of

${ }^{4}$ Some recent cost estimates for the technologies considered in this report are discussed in the report Technical and Economic Feasibility of Alternative Fuel Use in Process Heaters and Small Boilers, U.S. Department of Energy (DOE/EIA-10547-01, February 1980), pp. 4-1, 4-45. See also Cost Technologies Market Analysis, Engineering Societies Commission of Energy, Inc., Washington, D.C., January 1980. 
coal in the industrial sector. The reader primarily interested in industrial coal demand within the 1990 time frame can skip this discussion without loss of continuity and turn to Chapter 3.

\section{Low- and Medium-Btu Gases}

Coal-derived gases are produced by injecting a hot bed of coal with oxygen and steam. Medium-Btu gas (MBG), manufactured using oxygen firom an oxygen plant, has a heating value ranging from 200-500 Btu/standard cublc foot (SCF). Low-Btu gas (LBG), manufactured using air as the source of oxygen, has a heating value between 100 and 200 Btu/SCF. The efficiency of the gasification process (the Btu contained in the gas produced as a percent of Btu in coal feedstock) varies between 65 and 92 percent depending on the design of the coal bed and the composition of the coal being gasitied. High-beu gas 15 nor expllelliy emmilletel $\dot{i}^{\prime}$ this report sinec it is indistinguishable. from natural gas to the end-user.

The conversion of coal to coal gases makes it feasible to indirectly use coal in furnaces designed to burn oil and natural gas. Coal gas can be cleaned of contaminants or it can be used in a raw form directly from the gasifier. The flame temperature of coal gas is considerably lower than that of natural gas and the volume of combustion products per Btu of coal gas is higher than that of either natural gas or fuel oil. As a result, the use of coal gas in equipment designed to burn oil or natural gas can cause significant reduction in the capacity of the furnace. 
Coal gas can be used as a boiler fuel in new units or as a retrofit to existing oil and natural gas units. As a boiler fuel, cleaned coal gas may be used as an environmentally acceptable way to substitute coal for oil and natural gas in moderately sized existing and new units.

In process heat applications the use of coal gas greatly extends the range of applications that can technically use coal. For example, process heaters in the food industry (e.g. ovens) cannot use coal directly due to the presence of contaminants. Low- and medium-Btu gasification has existed for several decades, and no significant technical problem remains to inhibit the commercialization of coal gas as an industrial fuel. The next chapter of this report revicws the technical feastbility of using coal and coal-derived fuels for many major industrial energy use applications.

\section{Solid Solvent Refined Coal (SRC-1)}

Solid solvent refined coal $(\mathrm{SRC}-1)$ is produced by dissolving pulverized coal in a coal-derived solvent at a high pressure and temperature. Und1ssolved matter is filtered and the coal which is then solidified at about $355^{\circ} \mathrm{F}$.

The principal advantage of SRC-1 over direct coal use is that it contains smaller amounts of ash and sulfur. The lower ash content prevents the fouling and slagging of combustors and, therefore, would potentially increase the availability of each boiler. This lower ash content also makes the use of SRC-1 possible in some combustors in which coal use is infcasible because of the quantities of ash produced during combustion. 
The lower sulfur content eliminates the need to install a flue gas desulfurization (FDG) system. Whether SRC-1 is cost effective; however, with competing technologies, such as direct coal combustion with FGD or $A F B C$, remains to be determined.

The energy efficiency of the conversion plant is expected to be approximately 65 percent. When made from high sulfur bituminous coal, SRC-1 contains approximately 0.15 percent ash and a low 0.84 percent sulfur on an as recovered basis. $S R C-1$ has a relatively high heating value of $15,700 \mathrm{Btu} / 1 \mathrm{~b}$.

\section{Liquid Solvent Refined Coa1 (SRC-2)}

The liquid solvent refined coal (SRC-2) process is a modification of the SRC-1 process. SRC-2 starts w1th the blending of a recycled coal/coal liquid slurry into the incoming pulverized coal steam. The resulting slurry then is heated and reacted with hydrogen at about $875^{\circ} \mathrm{F}$ and $2000 \mathrm{psi}$ (pounds per.square inch) pressure. As the coal molecules are broken down in this reaction, organic sulfur and light hydrocarbons are released and evolved as gases.

The liquid product of this step is separated by vacuum distillation to produce the liquid fuel products and the heavy bottoms that are gasilied to produce hydrogen for the process. Vacuum distillation also is used to separate the ash from the fuel. This process is estimated to be about 65 percent efficient. 
The mix of fuels produced can be altered by changing the operating conditions. Typically, 75 percent of the liquid product mix can be used for low sulfur industrial fuel, 19 percent for refinery feedstocks, and 6 percent for residential and commercial heating oil.

The reduced ash and sulfur composition of SRC-2 alleviates operational and air pollution problems experienced with direct coal combustion. SRC-2 is considered to be a low sulfur, low ash fuel; it usually does not require the installation of an FGD unit. In general, SRC-2 burns with a long, luminous flame similar to the flame of Number 6 (residual) fuel oil.

\section{Coa1/Oil Mixtures}

Coal/oil mixtures (COM) have been developed as a hybrid fuel to enable the use of significant amounts of coal in processes otherwise incapable of using solid fuels, without major renovation. To form COM, finely pulverized coal (200 mesh) is blended with residual oil in a homogeneous slurry. The coal composition of the mixture usually varies between 20 and 50 percent, depending on process requirements. When heated, this mixture behaves less like oil and is more difficult to handle. This can increase costs and the likelihood that the fuel will be incompatible with specific processes.

If COM is allowed to stand, the coal particles in the mixture settle. Since a nonhomogeneous mixture can cause problems in storage, pumping, and 'combustion, the mixture must be agitated constantly or constituents 
must be added to the mixture to increase the ability of the coal to remain in suspension. 5

Since COM is a slurry mixture in which the coal particles are held in suspension, the more homogeneous the mixture, the better the fuel performs both in combustion and in handling. Residual, rather than distillate, oil must be used since the viscosity of dist1llate ofl is too low to maintain the coal particles in suspension. Like residual oil, COM must be heated to $150-170^{\circ} \mathrm{F}$ to be pumped and to about $200^{\circ} \mathrm{F}$ to be sent to the burner. The heating value of the fuel is somewhat lower than that of residual oil due to the lower heating value of coal on a Btu/volume basis.

Because COM requires a larger volume for complete combustion than either natural gas or oil, a furnace originally designed for oil/gas firing may undergo derating (burn fewer Btu per unit of time than the design capacity). The extent of derating can vary from one to 10 percent, depending on many factors. Insufficient burn tests have been conducted to facilitate systematic evaluation of the derating process.

The ash and sulfur emissions from the combustion of COM will vary directly with the amount and type of sulfur and ash that are in the coal and residual oil that make up the mix. Nevertheless, these emissturis almust always will be high enough to raise concerns about ash deposition and sulfur-induced corrosion. NO (nitrous oxides) formation in COM combustion is much the same as in combustion of the parent fuels.

${ }^{5}$ Recent use of ultrasonic agitation by Coaliquids, Inc., appears to be a promising new development. 
Although there are no major unresolved engineering problems constraining this technology, it is considered unproven due to a lack of data concerning the results of prolonged use of COM on the systems' 1ongevity, derating, fuel handiing (settling), and emissions. 


\section{COAL USE IN ENERGY INTENSIVE INDUSTRIES}

Seven major energy intensive manufacturing industry groups accounted for roughly 69 percent of total coal, natural gas, distillate and residual fuel oil consumption (excluding raw material and feedstock uses) in the manufacturing sector in 1974.1 These industry groups were food; textile; stone, clay and glass; petroleum; chemicals; steel; and aluminum. Unlike in the paper industry, each relied on natural gas as the primary fossil fuel for heat and power. Power plants on the East Coast relied primarily on residual fuel oil in 1974; paper plants in the Midwest, South, and West, however, purchased more natural gas than any other fuel type except wood waste. Among industrial groups, coal was used primarily as a boiler fuel, except in the stone, clay, and glass industry in which coal was burned in kilns to calcine raw materials for cement and lime production. Since 1974 , industrial coal use has remained fairly stable. In 1979, 66 million tons in 1974.

The direct use of coal as a boiler fuel is not constralned by the Lechuical factors considered in this report. Coal can feasibly be burned even in the smallest of boilers. A recent report prepared for the Environmental Protection Agency $^{2}$ indicated that about 7 percent of boilers with a design capacity of 10 million Btu per hour or less were designed to burn coal.

${ }^{I}$ Energy Consumption Data Base, Energy Information Administration, U.S. Department of Energy, 1977. This data base is currently being updated to include data through 1976. At this time, the Energy Consumption Data Base is the only comprehensive source of information on the functional uses of industrial energy.

2 PEDCO Environmental Inc., "Population and Characteristics of Industrial/Commercial Boilers," prepared for the Environmental Protection Agency, May 1979. 


\section{$\cdot, \cdot$,}

As previously stated, coal used in conventional boilers dominates projections of industrial coal demand within the 1990 time frame About four-fifths of industrial, (nonmetallurgical) coal demand is now consumed in boilers. 3

Process heat use of coal is limited primarily by technical and lead time considerations. Coal-based alternatives to natural gas and oil use in process heaters are discussed below at a process and industry specific level. Only at this level can fuel choices be assessed reasonably.

\section{Food Industry}

Most of the diverse processes in the food industry utilizing direct firing are constrained by strict requirements for clean fuels and fuels that are highly controllable. To avoid contamination that would seriously impair product quality, heavy hydrocarbon fuels containing ash and sulfur and those which form soot cannot be utilized. Natural gas is the major fuel used for direct firing in the food industry. Distillate oil has been used when natural gas was unavailable, but it requires an expensive unit to vaporize the fuel prior to combustion.

Clean coal gas is the only coal based energy source considered feasible for direct use in the food industry. However, indirect coal use through

3 Op.cit., Energy Consumption Data Base, 1974. 
greater reliance on electricity produced in coal-fired boilers and indirect heating methods may become increasingly important in the food industry in the future. 4

Coal, raw coal gas, COM, SRC-1, and SRC-2 are considered infeasible because of product contamination problems.

\section{Texlile Industry}

Direct firing in the textiles industry, primarily used in singeing, drying, and heat setting, requires clean and highly controllable heat to maintain proper product quality. In some processes, the use of soot-forming fuels is not detrimental since products are, or can be, washed subsequent to finishing. Final processing; however, would not permit soot contamination. In addition, many fuels containing soot and ash are not highly controlled and, thus, would not be appropriate tor the textile industry.

${ }^{4}$ In indirect heating systems, working medium, such as steam, picks up heat energy from a combustor and then flows through a piping network to distribute the heat throughout the process plant. Ihere is no direct energy transfer from the combustor to the process; instead, energy 1s transferred through an intermediate step by way of the wurking fluid. After the heat has been released to the process, the working fluid is collected and returned to the combustor to repeat the cycle. Closedloop operation of the working fluid is typical of indirect heating systems.

5 .his assessment is the conclusion of engincering analyses conducted to support the report cited previously, Technical and Economic Feasibility of Alternative Fuel Use in Process Heaters and Sma11 Boilers, pp. 5-14. 
Natural gas currently is the dominant fuel used in the textile industry. During natural gas curtailments; many mills simply shut down. Mills that do switch to distillate oil are able to operate some units successfully, but maintenance costs increase.

The use of clean coal gas, indirect heat, and electrification are considered feasible in new units. Coal, COM, SRC-1, SRC-2, and raw coa1 gas are considered infeasible for use in textile process heaters due to fuel contamination levels.

$$
\text { Stone, Clay, and Glass Industry }
$$

The industries considered as stone, clay, and glass industries are cement, lime, clay, brick, and glass manufacturers. Natural gas is the dominant fuel now used in all but cement and lime kilns. Historically, "producer gas" from coal gasification units was used before natural gas became widely available. Combustors in this industry differ considerably in their ability to use coal. Unit melters in the glass industry, for example, can use either raw or clean coal gas but in many applications cannot use coal directly due to product contamination problems. In the cement industry, alternatively, the contaminations contained in coal do not detract from product quality and form part of the necessary raw material for the production of cement.

Through 1990, most coal used in the industrial process heater category will be consumed in cement and lime rotary kilns. These combustors are already consuming large quantities of coal, SRC-1, SRC-2, raw coa1 gas 
and clean coal gas àre considered feasible alternatives in cement and lime rotary kilns. 6

Petroleum and Themicals

Fired heaters used in chemical and petroleum processing are extremely large consumers of energy. Together these industries used 44 percent of the natural gas and 38 percent of the fuel vil consumed in industrial process heaters in 1974. Whether coal-based fuels can puleulially displace this use of scarce fuel depends upon the temperature required by the process, the reactivity and coking potential of the feedstock, and the degree of heat distribution control required for proper processing. Units operating at temperatures below $800^{\circ} \mathrm{F}$ have a low potential for coking and generally are less demanding in terms of the precision and quality of the heat delivered. 'lubesstill heaters used for alkylation and atmospheric distillation are included in this group. In new units, with a design firing rate greater than 50 million Btu per hour, all of the coal or coal-based alternatives discussed in Chapter 1 are considered feasible (direct coal use, SRC-1, SRC-2, COM, clean coal gas. raw coal gas). ${ }^{7}$ In smaller units, STC-1 and direct coal use may not be feasible due to burner size and tlame stability requiremenls.

6

Ibid. , pp. 5-18.

7.Ibid. , pp. 5-19. 
Units that operate at high temperature, possess a strong potential for coking, 8 and require precise heat control cannot use the coal-based alternatives discussed in this report. Such high risk units include the production of ammonia and ethylene in the chemical industry, and thermal crackers and wisebreakers in the petroleum industry.

As previously mentioned, the designation, "feasible" does not indicate that a technology. is economically attractive. This caveat is particularly noteworthy for the petroleum refining industry. Fuels similar to residual fuel oil and natural gas are byproducts of refinery operation. These fuels are available and inexpensive to use. Consequently, the displacement of these internally generated byproduct fuels with coal-derived fuels is unlikely.

Steel and Aluminum Industries

Natural gas provides about two-thirds of the process heat energy requirements of the primary metals industry. Natural gas use in the steel industry could feasibly be reduced by greater reliance on coal-based fuels. In some furnaces, such as traveling grate furnaces, fuel ${ }^{\circ}$ is used to ignite or fire the moving beds that carry the sinter and iron ore products. Since the products of these furnaces go to the blast furnace, there are minimal constraints on contaminants. The use of COM, coal, SRC-1, SRC-2, and raw and clean coal gas are all considered feasible in this application. 9

8 The accumulation of unacceptable coke deposits in tubes containing feedstock.

${ }^{9}$ Op.cit., Technical and Economic Feasibility of Alternative Fuel Use in Process Heaters and Small Boilers, pp. 5-22. 
However, the use of internally derived byproduct fuels, when available, is a more logical and economic choice for most units in the steel and aluminum industries.

Aluminium rotary kilns, while essentially the same as lime and cement kilns, cannot use fuel containing significant levels of contaminants. The predominant fuel used is natural gas, and only the use of clean coal gas is considered a feasible coal-based alternative. 


\section{FACTORS AFFECTING INDUSTRIAL COAL USE}

The previous sections have discussed the echnical feasibility of increasing the industrial sector's reliance on coal. This section focuses on key factors affecting Industrial coal use within the next decade. Coal use in boilers' and kilns (existing and proven technologies) will dominate industrial coal use during this period," Since the focus of this report is industrial coal use by 1990 , the market penetration of the coal-based technologies described previously is not considered further in this. report. Forecasts of industrial coal use appearing in Chapter 4 include only conventional uses of coal.

The direct use of coal in other process heaters, even where feasible, may take a considerable length of time for commercial demonstration and industry acceptance. Similarly, coal-based synthetic liquid and gaseous fuels may require a considerable time period before large scale production and use can be achieved.

Factors affecting future levels of industrial coal demand include:

- Fuel prices and availability

- Environmental regulations and costs of meeting regulations

- Energy legislation that promotes greater reliance on coal. in the industrial sector

The industrial sector, the largest consumer of energy in the economy, accounted for 37 percent of total domestic energy consumption in 1979.

${ }^{1}$ Monthly Energy Review, Energy Information Administration, U.S. Department of Energy, June 1980, np.16. 
This consumption level. however, is not the sole reason this sector plays such a critical role in national energy policy. Just as important is - the fact that coal and coal-based synthetic fuels can be used to reduce this sector's reliance on natural gas and oil. Much recent energy legislation is designed to increase and hasten this change. ${ }^{2}$

Coal is a technically feasible alternative to oil and gas use in boilers of all sizes - - even bulleis with a design flring ratc of less llian 1 million Ptu per hollt liave becn bulll that hurn coa1. 3

The decision to purchase coal-fired equipment is based on economic cousiderations and environmental regulations and not on uncertainties about the feasibility of burning coal. Historical evidence indicates that in the decade before the 1973 oil emhargo coal use in hoilers had not been competitive with natural gas and oil. Coal use declined during this peliod bccaue relatively Inexpensive, clean, and easy-tu-insta11 and operate gas- and oil-fired boilers were available. These units were much smaller than their coal-fired counterpart, required relatively little or nn space for fuel storage and handling facilities, and could be delivered as a "package unit." Large coal-fired units, in contrast, are far tuo large to he shop-assembled. Lengthly (and expensive) field assembly is required and a subslantial amounl nf opace is needed both outside and inside the powerhouse to stockpile coal and for coal handling and ash disposal equipment (conveyers, crushers, pulverizers, etc.).

2 See the Powerplant and Industrial Fuel Use Act of 1978, and the Energy Tax Act of 1978.

${ }^{3}$ Coal use in existing bollers, not originally designed to burn coal, is usually not a feasible alternative. 
Natural gas and oil-fired units are considerably less expensive than a comparable coal-fired unit. Even before pollution control equipment was mandated by the Clean Air Act of 1970, the direct capital cost of a coal unit was more than $2 \frac{1}{2}$ times the cost of comparably sized gas-fired units. More recently, the direct capital cost of a coal unit has been estimated to be more than four times that of a gas unit. 4

Natural gas and oil account for about two-thirds of the fuel used in. industrial boilers. ${ }^{5}$ Given the proven nature of coal use, it's not surprising that much recent energy legislation attempts to increase reliance on coal as a boiler fuel. Special investment tax credits are designed to decrease the relative capital cost of burning coa1, 6 and fuel price surcharges on natural gas have increased the fuel price advantage projected for coal. 7

It is more difficult to evaluate fuel choices in process heaters than it is to examine fuel choices in boilers. Boiler components are relatively homogeneous across a wide range of sizes and applications, while process heaters comprise a large number of extremely diverse combustors. The temperature requirements for these combustors range from $450^{\circ} \mathrm{F}$ for baking in the food industry to more than $2500^{\circ} \mathrm{F}$ in regenerative furnaces in the glass industry.

${ }^{4}$ Industrial Fuel Choice Analysis Model (IFCAM) Volume II, Energy and Environmental Analysis, Arlington, Virginia, January 1979, Table A.10.

${ }^{5}$ Ibid., pp.3-23.

6 Energy Tax Act of 1978.

7 Natural Gas Policy Act 1978. 
Site-specific factors are alsó more difficult to assess in process heaters than in boilers. ". Since few process heaters are available in packaged units, each combustor generaliy is designed to meet specific space. requirements, temperature requirements, input fuel specifications, operating parameters, and environmental regulations. Even for similar processes, design specifications vary from company to company.

Within the 1990 time 'frame, most coal use in the process heater category will be consumed in kilns in the cement and lime industries. Th1s is d proven technology already penetrating the market: Cement and lime kilns currently consume more than four-fifths of the coal used in process heaters. 8 The remainder is consumed as coke oven gas in reheat furnaces and coke ovens, and, as blast furnace gas in blast furnace stoves and snaking pits.

\section{Indülíial Einergy Prices}

Coal is currently the least expensive fossil fuel delivered to the industrial sector. ${ }^{9}$ In 1978 its price in energy equivalent terms was about 14 percent below that of natural gas and 46 pereent bclow that of residual oil. As Table 1 shows, however, thl's tue $\perp$ price advatirage has not always existed. Natural gas enjoyed more than a 30 percent price advantage over coal in the decade preceding the oil embargo of 1973 .

\footnotetext{
${ }^{8}$ up. eit., Technical and Fconomic Feasibility of Alternative Fuei Use in Process Heaters and Small Boilers, pp. 3-31.

${ }^{9}$ This report does not consider regional differences in fuel prices. Price data presented represent national average prices. In the Southwest for example, natural gas is currently the least expensive fossil fuel. 
Given the relatively low capital cost associated with using natural gas, it is not surprising that -industrial reliance on natural gas increased rapidly during this time period. In contrast, between 1965 and 1973 the industrial demand for coal declined at an average annual rate of more than 5 percent. Projections of industrial fuel prices for 1985 through 1995 are also presented in Table 1. These projections were made as part of the Midterm Energy Forecasting System (MEFS) analysis for the 1979 Energy Information Administration's Annual Report to Congress. Projections based on the Medium World 0il Price scenario are reported in this table. 10

Delivered coal prices to the industrial sector are projected to increase at a much slower rate than other fossil fuel prices. Over the entire forecast period (1978-1995) the price of coal (adjusted for inflation) increases at an average annual rate of 3.4 percent, compared to rates of growth of 7.6 percent for natural gas and 6.1 percent for residual fuel oil. By 1995, coal delivered to the industrial sector is estimated to cost less than half of the price of natural gas and about one-third of the pricc of residual oil oni a BLu equivalent basis.

\section{Environmental Regulations. Affecting Coal Use}

The Clean Air Act (CAA) of 1970, along with major amendments adopted in

${ }^{10}$ International $0 i 1$ Price (1.979 \$ per barrel)

$\begin{array}{ll}1985 & \$ 32.00 \\ 1990 & \$ 37.00 \\ 1995 & \$ 41.00\end{array}$


Table 1. Industrial Energy Prices - History and 1979 Annual Report to Congress, Medium Case Projections, 1965-1995

(1979 dollars per million Btu)

\begin{tabular}{lccccc}
\hline & \multicolumn{3}{c}{ History } & \multicolumn{3}{c}{ Projections } \\
Fuel & 1965 & 1973 & 1978 & 1990 & 1995 \\
\hline Electrlc1ty & 6.41 & 5.96 & 8.34 & 1.2 .18 & 11.96 \\
Distillate 0il & 2.29 & 2.33 & 3.60 & 7.18 & 7.85 \\
Residual 0i1 & 1.24 & 1.72 & 2.49 & 6.22 & 6.83 \\
Liquid Gas & 1.90 & 2.37 & 3.42 & 8.83 & 9.56 \\
Coal & 1.03 & .98 & 1.34 & 2.26 & 2.36 \\
Natural Gas & .76 & .75 & 1.56 & 4.85 & 5.40 \\
\hline
\end{tabular}

Source: Energy Information Administration, Annual Report to Congress, 1979, Table 4.3. 
the Clean Air Act Amendment of 1977 , have brought significant changes to the Federal regulatory mechanism governing pollution and control. These changes have significantly increased the cost of burning coal relative to natural gas and low sulfur residual fuel oil. Although the complexity of the Clean Air Act precludes full discussion here, certain essential features of the statutory framework must be recognized in order to understand how the law may affect coal use in the industrial sector.

\section{Nationai Ambient Air Quality Standards (NAAQS)}

The CAA requires the Environmental Protection Agency (EPA) to develop two kinds of standards for ambient air quality -- "primary" standards necessary to protect public health, and "secundary" standards designed to protect public welfare. To date, the EPA has established standards for seven major classes of pollutants: (1) particulates, (2) sulfur dioxide $\left(\mathrm{SO}_{2}\right)$, (3) carbon monoxide (CO), (4) ozone, (5) hydrocarbons (HC), (6) nitrogen dioxide $\left(\mathrm{NO}_{2}\right)$, and $(7)$ lead $(\mathrm{Pb})$. EPA has developed both short term and long term exposure standards for these pollutants.

Short term standards establish limits on emissions for periods of 24 hours or less. Long term standards cannot be exceeded on an annual basis.

To coordinate the control of air pollution, the EPA divided the country into 247 Air Quality Control Regions (AQCR's). These reginns can be intcr.. state or intrastate areas. They are formed according to meteorological, industrial, and socioeconomic factors and should be treated as a single unit for the purpose of controlling air pollution. EPA and individual states have designated areas of the country that do or do not meet NAAQS, 
or for which there is insufficient data to place them in either of these categories, Classification of an area determines what actions the state and EPA will be required to take to regulate air pollution from existing and new emission sources. An area is designated a nonattainment area (NA) with respect to a particular pollutant if it is not in compliance with these standards.

\section{State Implementaliun Plans (SIIs)}

State Implementation Plans are the mechanisms by which individual states implement, maintain, and enforce the regulations and provisions of the CAA. Each state is required to submit this plan for EPA approval. Construction of new major emitting sources is prohibited for any source emitting a nonattainment pollutant in a nonattainment area in a state without a fully or conditionally approved SIP.

SIPs vary substantially within and between states, both in severity of the standard and the way they are expressed.

\section{State New Source Review Regulations}

Inder, the Clean Air Act, SIPs must assure attainment of NAAQ3 by December 31 , 1982; if severe oxidant and carbon monoxide problems exist, the dead1ine may bc exLented to December 31, 1987. As part of an effort to meet these deadlines, as well as to maintain air quality in areas meeting NAAQS, many states implement New Source Revlew (NSR) programs to regulate new sources of air pollution. NSR programs generally require new sources to implement best available control technology (BACT), and to undergo air quality assessment to demonstrate that emissions from the new 
source will not interfere with the maintenance or attainment of any State or national ambient air quality standards. Most NSR programs cover more sources and have stricter requirements than Federal Preventions of Significant Deterioration (PSD) and nonattainment provisions.

\section{Prevention of Significant Deterioration (PSD)}

PSD provisions are designed to protect air quality in areas now meeting all ambient air quality standards: PSD limits the degradation of air. quality in so-called "clean-air" areas, provides a mechanism to regulate pollutant emission from new sources, and allows states to determine the degree of new source growth desired in clean air areas. These functions are carried out through specific requirements, all of which are to be incorporated into SIPs.

The regulatory effect of NA/PSD requirements is as follows: If NAAQS are not met in an area, NA rules must be met for each new or expanded facility. When NAAQS are met, PSD rules apply. NA provisions, in general, require that states include in their SIPs special provisions designed to upgrade nonattainment areas. PSD rules require that states maintain, above EPAapproved levels, the air quality of their clean air areas.

$$
\text { New Source Performance Standards (NSPS) }
$$

NSPS are Federa1 standarda governing emfsșions from new or modified stationary sources. These standards comprise the least stringent emission limitations to which applicable new sources are subject; individual states, through implementation of new source preconstruction revtews, may 
establish stricter pollutant emission restrictions. Emission standards are established by NSPS for categories of sources with respect to any type of air pollutant emitted.

Emission limits are now being revised by the EPA. These limits will affect both the fuel quality and pollution control equipment required of each combustor. Natural gas and distillate fuel oil are inherently clean fuels that will be able to satisty emisslon limits without pn1lution control equipment. Such equipment adds significantly to the cost of. burning coal. Unless BACT is mandated by regulation, the combination of control equipment and fuel quality requirements associated with sulfur and particulate emission limits is an economic choice. In the case of a combustor facing a sulfur dioxide regulation of $0.8-3.5$ pounds/million Btu, it may be cheaper to clcan a portion of the flue gas steam (partial scrubhing) instead of using a higher priced coal. Conversely, in the case of a small hoiler with a low capacity utllization rate, it may be better to utilize a very low sulfur coal to satisfy a 1.2 pounds/million Btu regulation instead of installing flue gas desulfurization (FGD) equipment.

The use of coal-based synthetic fuels (discussed in Chapter 2) may decrease the environmental costs associated with burning coal in the future. In the short term, acmospleric fluldized hed combustion of coal may be an economically attractive alternative to conventional coal use requiring FCD systems. 


\section{Energy Legislation Promoting Industrial Coal Use}

Until the oil embargo of 1973 and the ensuing leap in world oil prices, the pattern of industrial energy use and industrial technology development had evolved during a time of ample supplies of oil, natural gas, and other fuels and generally stable real energy prices. With low natural gas and oil prices, product and process designs were more energy intensive than they would have been if sharply increasing real energy prices had been widely anticipated. Several provisions of the National Energy Act of 1978 promote and hasten increased irdustrial reliance on coal and other alternative energy sources. These include: The National Gas Policy Act of 1978, the Powerplant and Industrial Fuel Use Act of 1978, and the Energy Tax Act of 1978.

Natural Gas Policy Act (NGPA)

The NGPA has two major components -- wellhead pricing controls and incremental pricing. The wellhead pricing regulations set maximum prices for various categories of natural gas sold to pipelines. It also provides for gradual escalation and eventual decontrol of certain categories of natural gas.

The incremental pricing rule may significantly affect coal use in boilers and process heaters. Pegulations have been issued that set an incremental price ceiling for natural gas use in boilers. The regulation specifies that, for 10 months, the gas price ceiling for nonexempt users will be set at a price determined by DOE to be two standard deviations below the 
mean high sulfur oil price for each region. At the end of 10 months, the incremental oil cap will be adjusted to reflect the actual backup fuel (high or low sulfur residual oil or distillate) that each boiler has in place. If no backup fuel exists, the gas: price ceiling automatically will be set at a distillate (the two standard deviation rule would still be in effect).

Currently, the incremental pricing provisions apply only to facilities that consume more than 300 million cubic feet per day in boilers (roughly equivalent to one 25 million Btu per hour boiler operating 12 hours per day at full capacity).

Powerplant and Industrial Fuel Use Act (PIFUA)

PIFUA provides the Department of Energy with the authority to prohibit the use of oil or natural gas in all boilers over 100 million Btu per hour, and in existing boilers over 100 million Btu per hour that originally were designed for, and still have, coal burning capability. The prohibltion also extends to new boilers between 50 and 100 million Btu per hour if the aggregate plant boiler capacity is over 250 million Btu per hour (aggregation rule). It is very difficult to estimate the portion of small boilers that will be covered by this rule since no comprehensive survey has been conducted for boilers under 100 million Btu per hour. ${ }^{11}$ The Act provides some discretionary authority over gas turbines, internal cumbustiui engines, and combined cycle systems, although DOE has not yet defined the extent of that authority,

${ }^{11}$ Boilers with a design firing rate of 100 million Btu per hour or greater are covered by the Major Fuel Burning Installation survey conducted in 1976. 
Any unit subject to the prohibitions of PIFUA can apply for one of several exemptions. Three major exemptions are;

- The economic exemption

- The environmental exemption

- The temporary exemption for those who have made a commitment to use a synthetic fuel

An economic exemption can be claimed if the cost of using coal (or other available alternative energy sources) is substantially greater than the cost of using world oil. 12

Energy Tax Act (ETA)

The ETA provides financial incentives to burn alternative fuel types in both boilers and process heaters. The ETA provides for a 10 percent investment tax credit (ITC) in addition to the existing 10 percent ITC for units burning an alternative fuel type. Units burning oil and natural gas are denied the existing 10 percent ITC.

In addition, investments in alternative fuel burning capacity can use accelerated depreciation methods for tax purposes while oil and gas investments are required to depreciate using the straight line method. Provisions of the Energy Tax Act are due to expire in 1982, but the Crude Oil Windfall Profit 'lax Act of ' 1980 extends the coverage for wind and solar equipment through 1985 and increases the special ITC to 15. percent.

12 Other site-related exemptions may be cla1med if delivery of an alternate fuel source cannot be secured that meets environmental restrictions. 


\section{FORECAST OF INDUSTRIAL COAL USE ${ }^{1}$}

The outlook for industrial coal use a decade ago was one of continued stagnation and decline. With the exception of coal used as a feedstock in the production of steel, coal was a declining industrial energy source. In the decade preceding the 1973 oil embargo, such industrial coal consumption declined at an average annual rate of 4 percent and there was little reason to belleve this decline would not accelerate. Natural gas use had nearly doubled during this period and the Clean Air Act of 1970 had significantly decreased the attractiveness of cozl relative to clean natural gas.

By 1979 the picture had changed dramatically. 'Residual fuel oil prices to the industrial sector were about twice what they were in 1970 . Natural gas prices were more than twice their 1970 level. The 1973 oil embargo, furthermore, had vividly demonstrated the danger of being dependent on foreign sources of energy. Coal, for decades a declining industrial fuel, is now considered by many to be our "ace in the hole." Greater industrial reliance on coal has become a basic tenet of the Nation's energy policy.

Chapter 2 of this report considered the technically feasible uses of coal. in the industrial sector in the short and long term. Within the next decade, conventional coal technologies (coal use in boilers and

${ }^{1}$ Unless otherwise noted, forecasts presented in this report were developed for the Medium World Oil Price. Scenario of the Energy Information Administration's Annual Report to Congress, 1979. 
cement and lime kilns) will dominate industrial coal use, In the longer term, synthetic liquid and gàseous coal-derived fuels may greatly extend the industrial sector's reliance on coal. Chapter 3 considered several key factors that will affect the extent and speed with which the industrial sector switches to coal. This chapter presents and analyzes industrial fuel use projections developed for the 1979 Energy Information Administration's Annual Report to Congress, Volume III.

As previously stated, the forecasts presented in this report consider only conventional coal use. Table 2 shows historical and projected industrial fuel consumption levels. A distinct break with the past is projected. In 1978, distillate and residual fuel oil provided nearly 12 percent of the total energy consumed by industry. By 1990, they are projected to account for less than 2 percent. In contrast, industrial coal consumption increases dramatically, nearly doubling its market share by 1990. Most of this projected increase in coal consumption is in conventional boilers, where coal use is not limited by technical problems. Industrial coal demand by 1990 (including metallurgical coal demand) is projected to reach 7.3 quadrillion Btu (out of a total domestic coal consumption level of 26.8 quadrillion Btu) or about 27 percent of total domestic coal consumption. In comparison, in 1978 this sector accounted for only about 10 percent of domestic consumption. Thus the industrial sector is projected to nearly triple its relative share of the domestic coal market. 
Table 2. Industrial Energy Consumption: History and Projections, 1965-1995

\begin{tabular}{|c|c|c|c|c|c|c|c|c|c|c|}
\hline \multirow[b]{3}{*}{ Fuel } & \multicolumn{6}{|c|}{ History } & \multicolumn{4}{|c|}{ Projections $^{a}$} \\
\hline & \multicolumn{2}{|c|}{1965} & \multicolumn{2}{|c|}{1973} & \multicolumn{2}{|c|}{1978} & \multicolumn{2}{|c|}{1990} & \multicolumn{2}{|c|}{1995} \\
\hline & $\overline{\mathrm{A}}$ & $\bar{B}$ & $\overline{\mathrm{A}}$ & $\bar{B}$ & $\overline{\mathrm{A}}$ & $\bar{B}$ & $\overline{\mathrm{A}}$ & $\mathrm{B}$ & $\bar{A}$ & $B$ \\
\hline Electricity & 1.5 & 8.2 & 2.3 & 10.0 & 2.1 & 12.3 & 4.6 & 17.2 & 5.5 & 18.6 \\
\hline Distillate Oil & 0.7 & 3.8 & 0.9 & 3.9 & 1.2 & 5.5 & 0.4 & 1.5 & 0.4 & 0.4 \\
\hline Residual Oil & 1.2 & 6.6 & 1.3 & 5.7 & 1.5 & 6.8 & 0.1 & 0.4 & 0.2 & 0.7 \\
\hline Liquid Oil & 0.3 & 1.6 & 0.6 & $2: 6$ & 0.8 & 3.6 & 0.7 & 2.6 & 0.8 & 2.7 \\
\hline Coal ${ }^{b}$ & 5.4 & 29.5 & 4.4 & 19.2 & 3.4 & 15.5 & 7.3 & 27.2 & 7.9 & 26.8 \\
\hline Natural Gas. & 6.8 & 37.2 & 9.6 & 41.9 & 7.9 & 35.9 & 7.8 & 29.1 & 8.1 & 27.5 \\
\hline Other & 2.5 & 13.7 & 3.8 & 16.6 & 4.5 & 20.0 & 6.0 & 22.4 & 6.7 & 22.7 \\
\hline Tota1 & 18.3 & & 22,9 & & 22.0 & & 26.8 & & 29.5 & \\
\hline
\end{tabular}

Medium World Oil Prices projection series, Energy Information Administration, Annual Report to Congress, 1979, p.93.

${ }^{b}$ Coal consumption includes metallurgical coal consumption.

Note: Column A lists quadrillion Btu; Column B lists percentages. Quadrillion Btu is used in this table in order to facilitate comparisons among fuels. Many coal consumntion numbers in the text are derived from this table based on a conversion factor of 22.5 million Btu per ton. 
Factors contributing to the projected fuel mix shown in Table 2 have already been discussed in Chapter 3 of this report. Relative energy prices and specific provisions of the National Energy Act are responsible for the shift toward coal. Delivered residual oil prices are projected to increase at an average annual rate of 8 percent between 1978 and 1990, compared to an increase of only 4.4 percent for coal. Natural gas prices are projected to increase at an annual rate of nearly 10 percent over this period. Several elements of the National Energy Act of 1978 are designed to improve the competitiveness of coal.

In particular:

- The Natural Gas Policy Act of 1978 increases the price of natural gas to most industrial customers

- The Powerplant and Industrial Fuel Use Act of 1978 prohibits the use of oil and natural gas in new boilers with a firing rate of 100 million Btu per hour or greater

- The Energy Tax Act of 1978 provides for special investment tax credits and accelerated depreciation methods for investments in. coal and other alternative energy sources

Unçertainties Aceociated with Projections of Industrial Cual

Several caveats should be observed to put the forecast results presented earlier in proper perspective.

- The industrial fuel mix projections presented in Table 2 are hased on a comparison of the life-cycle cost of burning alternative fossil fuels: (1) distillate fuel oil (2) high and low sulfur residua'l fuel oil, (3) natural gas, and (4) coal of various sulfur levels. The paradigm of life-cycle cost minimization, while useful from a modeling standpoint, needs to be considered more closely. To the extent that life-cycle cost comparisons are not the sole basis upon which industrial decisions are made, the forecast levels of industrial coal consumption appearing in Table 2 may by somewhat overstated. This is the 
case since the economics of coal use improve with the length of the time period considered. In each year considered there are additional fuel cost savings available to weigh against coal's higher initial capital cost.

- There is' considerable anecdotal evidence that many firms consider a far shorter payback period than the physical life of the equipment. 2 Some companies may use discounted cash flow analyses for only 5 years because of (1) a desire to minimize capital expenditures on energy facilities, (2) uncertain fuel prices, and (3) the age of the existing plant, For example, replacing an existing natural gas-fired boiler with 5 years of useful life remaining with a new coal unit with a useful life of 30 years may wul wake much acnoc if tho ontire plant is arheduled for replacement in 5 years.

- Many such site specific factors which may constrain coal use, particularly in existing facilities, have not been thoroughly considered in developing the forecasts presented in Table 2 .

Other important factors include the availability of an adequate coal delivery network; the availability of space to store the coal and the equipment needed to prepare (crushers, pulverizers) and handle the coal and waste ash; required construction of the plant to fit the much larger coal boiler in the plant; and plant downtime required to install the coal-fired boiler system. Such factors may make it less likely that existing facilities, which are not covered by legislation, will convert to coal.

It should be stressed again that the forecasts presented in Table 2 do not consider the penetration of the coal-based fuels considered in Chapter 1 of this report. Increasingly in the latter years of the forecast period, conventlonal industrial coal use may be displaced and augmented by atmospheric fluidized bed combustion of coal and the use of coal-derived synthetic fuels.

2"Coal Use Economics.and Problems"; Energy and Environmental Analysis, Inc:, Arlington, Virginia; May 1978. 


\section{GPO SINGLE ISSUE AND ANNUAL ORDER FORM}

(For use in ordering EIA Publications only - Read Ordering Information Section before coinpleting form.) SEND ORDER FORM TO: Superintendent of Documents, U.S. Government Printing Office, Washington, D.C., 20402

Enclosed is \$— Check

$\square$ Money order, or charge to my Deposit Account No.

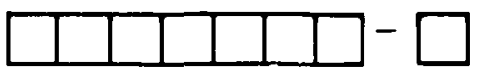

Order No.

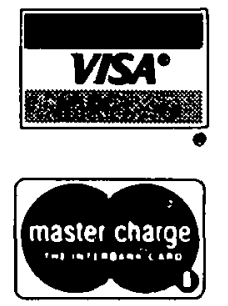

NAME AND ADDRESS

PLEASE PRINT OR TYPE

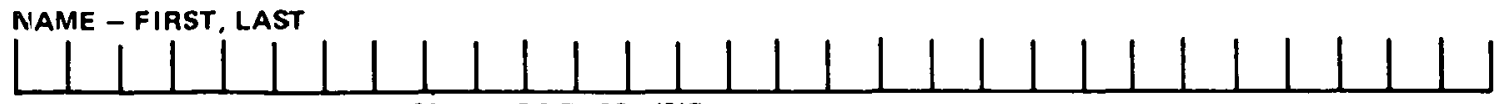

COMPANY NAME OF: ADDITIONAL ADDRESS LINE

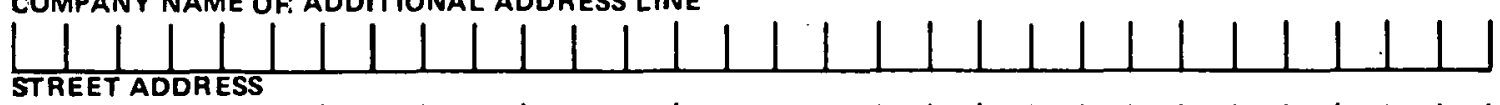

STREET ADDRESS

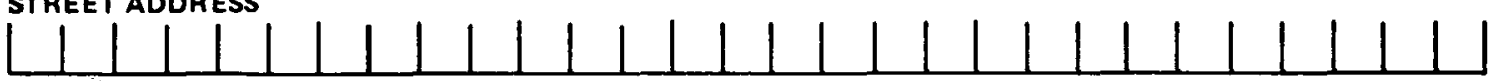

CITY - STATE ZIP CODE

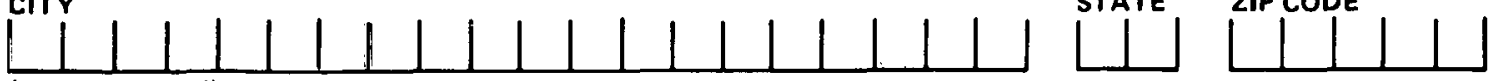

(OR COUNTRY)

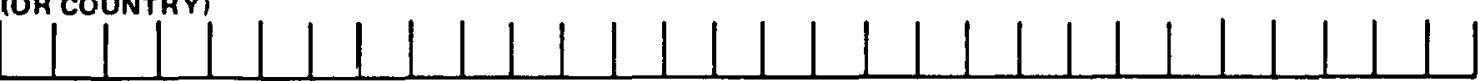

PLEASE PRINT OR TYPE THE GPO STOCK NO. OF SINGLE ISSUES OR ANNUALS YOU WISH TO RECEIVE:

Total charges $\$$

Fill in the boxes below

Credit

Expiration Date

Month/Year

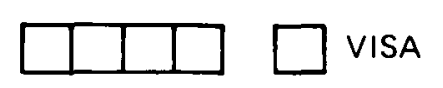

FOR OFFICE USE ONLY

QUANTITY

CHARGES

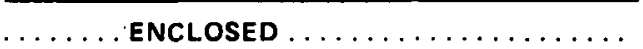

$\ldots \ldots$ TO

........ SUBSCRIPTIONS

POSTAGE

FOREIGN HANDLING $\ldots \ldots \ldots \ldots \ldots \ldots$

MMOB $\ldots \ldots \ldots \ldots \ldots \ldots \ldots \ldots \ldots \ldots \ldots$

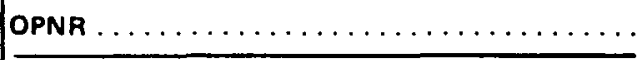

$\ldots \ldots$ UPNS

$\ldots \ldots$ DISCOUNT

REFUND

$+\cdots$ 


\section{U.S.'Department of Energy}

Energy Information Administration

Wàshington, D.C. 20585

$\therefore \quad$ OF ICIAL BUSINESS

PE⿱ 